\title{
The Influence of the Changing of Top Rich People in the 20th Century
}

\author{
Zhirui Fan
}

\author{
History, Capital Normal University, Beijing, 100089, China \\ CorrespondingE-mail : angela@cas-harbour.org
}

\begin{abstract}
Gilded Age is the key stage of the development of the United States. It can be said that it is the time to establish the position of the United States as a powerful country. This paper studies the ideological transformation of the top rich in the early 20th century and its influence. Through investigation, it is found that with the rapid development of economy and the aggravation of the polarization between the rich and the poor, due to the special role of various social aspects, there is a return of the concept of charity. Ideological change will inevitably have a significant impact on society. This study aims to provide the reader with a clear analysis of the social face of the Gilded Age in the United States, and also an opportunity to adopt other perspectives to understand the ideology behind the active participation of the wealthy in charity in today's American society.

Keywords: capitalists' rise, concept transformation, charity culture, various impacts
\end{abstract}

\section{INTRODUCTION}

The field of this paper is a link in the transformation of American social thought at the end of the Gilded Age (the beginning of the 20th century). The "Gilded Age" of the United States is an era of great economic development and constant creation of billionaires. After the baptism of the second industrial revolution, the American society changed dramatically. Now, the concept of "the fourth industrial revolution" has been put forward. Although for this revolution, international scholars have not made a final conclusion. However, the social background of gold plating era is similar to that of today, so it is of great significance to study its social characteristics. At present, many scholars in China think that China's economic and social environment is very similar to the gold-plated era in the United States. They hope to find the antidote to China's contemporary social problems through research. Chinese Professor Ding Zemin's "civil war and gilded age" and British scholar Gilbert's "American economic history" have both paid attention to the social characteristics of gilded age. But more works focus on industrial revolution, westward movement and workers' struggle, and less on the transformation of capitalist social role. I hope to explore this issue, deepen the understanding of the history of the United States, and also hope that this history can provide reference for the economic development and social transformation of China and the world today.

\section{THE BACKGROUND OF GILDED AGE}

The so-called "Gilded Age" comes from Mark Twain's first novel gilded age. It was between the civil war and the progressive era, from the 1860 s to the 1900 s. After the civil war, American society remained stable for a long time, which provided a favorable social environment for commercial development. At that time, it was the second wave of industrial revolution in the world, "electrical era" came, and the power industry, oil smelting industry, steel manufacturing industry, railway transportation industry, automobile manufacturing industry and financial industry developed rapidly. "The Great Plains, known as the "American Desert" before the Civil War, was developed into a vast "grazing kingdom" in a relatively short period of time."[1] In this industrial revolution, many capital tycoons took advantage of the situation. Most of them have poor family conditions, but with great courage and effort, they have accumulated a lot of wealth. Of course, there are also J. P. Morgan, who comes from a financial and banking family. At that time, the result of market competition was not only to "gild" many people, but also to give birth to new forms of production organization trust, cartel, etc., which can be collectively referred to as monopoly organizations. It also symbolizes the transition of capitalist economy from free competition to oligopoly. There is no denying that the "Gilded Age" is an era of making dreams. "A country has developed this vast land in such a short period of time. This is undoubtedly a magnificent epic. This phenomenon cannot be said to be unprecedented in history, but it can be said to be unprecedented....Western land The role of American capitalist development, no matter what kind of words are used to describe it, I am afraid it cannot be considered excessive." [2] This era is not only the foundation of countless American dreams, but also the key stage of the dream of American strength. The gilded age is a time of rapid development of American wealth. Millions of European immigrants have injected a large number of labor into the United States, which has led to the rapid 
development of many heavy industries such as railway, steel and mining. A large amount of wealth flows to the north and west of the United States, and then into the pockets of a group of monopoly capitalists.

But as Mark Twain wanted to express in the gilded age, the whole body of the United States at that time was full of corruption, or even all-round. Capital tycoons were once regarded as the pride of the United States, but the aggravation of social differentiation made people begin to despise them. In order to quickly accumulate wealth, Carnegie forced workers to work and cut wages, Rockefeller madly merged and killed small and medium-sized enterprises, and Morgan group used capital to speculate. Ida tabel, a "dung digger", regards them as "bandit tycoons" who take the pain of others as their source of happiness. Some media even call them "vampires".

It is not only the workers and other low-level societies that suffer, but also American politics is increasingly invaded by capital. Some even say that "the city government of the United States is the worst government in the Christian world - the most extravagant, corrupt and incompetent". By the beginning of the 20th century, a lot of wealth in the United States was concentrated in the hands of a few monopoly capitalists, and large consortia and rich people were emerging. At that time, the most famous monopoly capitalists in the United States were Rockefeller, Carnegie, J.P. Morgan and Henry Ford. They can involve not only the business sector, but also the politics, which has become the target of many people in American politics.

However, at the beginning of the 20th century, the image of those tycoons changed greatly, and they appeared as philanthropists and investors. The status of conspicuous leisure and conspicuous consumption in the life style of the upper class changes according to the different times. The stratum culture at the top of the wealth of the capital tycoons has been alienated.

\section{THE FACTORS BEHIND THE CHANGE OF CONCEPT}

This change of concept at the top of wealth can be said to be a great transformation. In short, in their original ideas and behaviors, wealth should be constantly gathered to their wallets; at the turn of the last century, they began to return their accumulated wealth to the society in various forms. There are many factors contributing to this transformation, including their personal factors and the influence of social background.

In terms of personal factors, these capital tycoons at the top of wealth are also individuals in society, whose psychology and behavior are naturally the research scope of sociologists. In the above, the author once mentioned that in his book on the leisure class, Van Buren analyzed and studied the specific leisure class. The leisure classes here are different in different times. For example, in the slave society, the leisure classes are those nobles who can have a greater power to allocate resources and have free time to engage in the consumption of spiritual resources such as literary creation.
In the gilded age, these capital tycoons are undoubtedly the most able to be called the "leisure class". According to the theory put forward by Van Buren, the way for the leisure class to show their status is not immutable. With the accumulation of time, they will gradually turn from focusing on their external wealth to showing their internal enrichment. The same is true of the top tycoons in the gilded age, who began to accumulate huge wealth in the 1860s and 1970s. Over time, they are no longer satisfied with material enjoyment, but pay more attention to their spiritual world.

Capitalists are also social individuals, whose psychology is also affected by society. In the second half of the 19th century, when the American social system was not perfect, many capitalists were born badly but could accumulate a lot of wealth. In addition to their own legitimate struggle, they could not help but fight with others. But over time, this sense of extreme competition is also weakening. At the same time, the problem of family inheritance began to be paid attention to by the capital tycoons. Through charity and other public welfare undertakings, we can create a good image of ourselves in the society and maintain the status of the family, which undoubtedly caters to their intention.

The implementation of political anti-monopoly and sharp social contradictions force capitalists to change their behavior style to obtain social identity and protect their own interests."Even any large enterprise combination, as long as it is reasonable, is allowed or even encouraged. Generous land grants, protective tariff rates, generous corporate laws, and simple tax policies support it."[3] In 1892, Standard Oil Company was ruled as an illegal monopoly enterprise, but Rockefeller escaped by transferring the property of the head office to its branches. Carnegie's steel companies also frequently strike workers, and its managers even privately employ Pinkertons to suppress with guns. William McKinley was elected in 1897. During his tenure as president of the United States, his economy was very good. He was even later called "prosperous president" by the American people. But his position was partly the result of the operation behind the capitalists, and during his tenure, many citizens thought it was the spokesman of the capitalists. The opinion of the public at the time commented: "The urban government of the United States is the worst government in the Christian world - the most extravagant, the most corrupt, the most incompetent."[4] McKinley was assassinated by anarchists in 1901. The poorest people crowded into shantytowns, such as Manhattan's " Five Points " and " Hell's Kitchen " community. These communities will soon be occupied by the infamous crime[5]. At that time, the public opinion began to denounce the monopoly in all walks of life. The "defecation movement" quietly rose. Many of books such as standard oil company history, the shame of the city and so on pointed to monopoly capital. After McKinley's death, the U.S. government's economic policy also changed significantly. Theodore Roosevelt came to power to promulgate the anti trust law and other laws, which dismantled many trusts. 
The transformation of social ideology and culture is also one of the key factors. Many of the capital tycoons at the top of the wealth are born in poverty, and their education level is not particularly high, but they pay special attention to the education of their children, and they are also keen to improve their knowledge to show their status. There will still be competition and competition among capitalists, but their objects will turn to charity oriented public welfare undertakings, and their sense of competition will also make the wind of charity sweep across the United States. Rockefeller and Carnegie can be taken for an example. They were business rivals when they were young, and they were not willing to lag behind in philanthropy in their later years. Slowly, this kind of atmosphere also makes American tycoons devote themselves to charity. It is worth mentioning that the concept of "equality of results" began to spread in the society, the public began to hate the innate privileges and resources obtained by the upper class, forced capitalists to change their thinking, and also made the government pay attention to social welfare.

\section{THE FAR-REACHING INFLUENCE AFTER THE TRANSFORMATION}

At the end of the 19th century and the beginning of the 20th century, it was the time when the United States strengthened its powerful public power. The U.S. government has passed a series of laws to force the capitalists to make concessions, thus avoiding the fate that the political field is completely eroded by capital. Bourdieu, a French sociologist, is the author of "practice and Reflection: the guidance of reflective sociology"[6]. In his book, he proposes that there are various fields in social space, and the diversity of fields is the result of social differentiation. Each field has certain autonomy. At that time, the United States gradually strengthened public power and maintained the autonomy of political field. But this is not the failure of American economic field. In fact, the "great transformation" of capitalists also promoted the transformation of monopoly capitalism at that time.

Capitalists and the state government began to improve the situation of workers. Although there have been many times in the future, this is undoubtedly a leap in industrial relations. It can even be said that this provided guidance for the construction of post-war "welfare state" and promoted the prosperity and development of American economy. Many capitalists began to take the world as their own duty, not limited to personal wealth. In Henry Ford's case, Ford finally realized the original pledge that he would let almost every family in the United States have a car, and the assembly line he invented made cars enter thousands of homes. At the beginning of the 20th century, the "defecating movement" not only influenced the capitalists, but also revealed many other aspects of the society. This movement has become a model for the press, and many journalists have begun to take revealing the deep social problems as their own duty, making journalism more and more the driving force for social development.
The capital tycoons of the "Gilded Age" devoted themselves to charity, which greatly changed the face of the American upper class. The upper class is more and more inclined to flaunt their temperament and knowledge, rather than show off their material wealth. Many billionaires set up their own charity foundations and managed their own charities through them, which also created a new mode for the top-level of wealth to engage in charity in the future. Driven by many factors, the concept of the top wealth of the "Gilded Age" has changed, and their image has changed from "vampire" to "philanthropist". This is not only their own transcendence, but also the achievement and driving force of social transformation. Since then, charity has become an indispensable label for a great business tycoon, and the social structure has changed a lot!

Of course, it also provides a shortcut for the top rich to avoid taxes. Many wealthy Americans set up trusts not only to better inherit assets, but also to exempt a large amount of federal inheritance tax by freezing some assets into the trust before their children reach adulthood. Take the most common stocks among the rich: in order to avoid a large amount of capital gains tax from trading common stocks, they will choose to convert common stocks into preferred stocks, then put some preferred stocks into trust funds, and finally use dividends as living expenses. This undoubtedly makes philanthropy become utilitarian and also a great challenge to the movement of social equality.

\section{CONCLUSION}

To conclude, with the rapid development of economy and the aggravation of the polarization between the rich and the poor, due to the special role of various social aspects, there is a return of the concept of charity. The author hopes to explore this issue, deepen the understanding of the history of the United States, and also hope that this history can provide reference for the economic development and social transformation of China and the world today. Limited by the base of knowledge of the author, there are still some shortcomings in this research. The lack of interdisciplinary combination of history, economics and sociology makes this analysis a little disordered. In the future, these deficiencies will be improved through actively expansion of knowledge of various areas.

\section{ACKNOWLEDGMENT}

First and foremost, I would like to show my deepest gratitude to my teachers and professors in my university, who have provided me with valuable guidance in every stage of the writing of this thesis. Further, I would like to thank all my friends and roommates for their encouragement and support. Without all their enlightening instruction and impressive kindness, I could not have completed my thesis. 
[4] A. Caltow, American Urban history: An Interpretative

\section{REFERENCES}

[1] G. Zhou, Capital Inflow in the Western American Pastoral Area during the Gilded Age, World History, vol. 4, 2004.

[2] S. Yang, American Historian Turner and His School, Beijing: The Commercial Press, 1983.

[3] G. Xu, Social and Economic Policies and Impacts of the American Gold-plated Era, Journal of Zhengzhou University, vol. 4, 2001.
Reader with Commentaries, New York: Oxford Univ.Pr., 1973.

[5] T. Anbinder, Five Points: The 19th-century New York City Neighborhood that Invented Tap Dance, Stole Elections, and Became the World's Most Notorious Slum, Simon and Schuster, 2001.

[6] P. Bourdieu, Practice and reflection - introspective sociological guidance, Central Compilation press, 1998. 